\title{
Hiking trails as conduits for the spread of non-native species in mountain areas
}

\author{
Rebecca Liedtke • Agustina Barros • Franz Essl • Jonas J. Lembrechts • \\ Ronja E. M. Wedegärtner · Aníbal Pauchard · Stefan Dullinger 1
}

Received: 11 March 2019/ Accepted: 26 November 2019/Published online: 4 December 2019

(C) The Author(s) 2019

\begin{abstract}
Roadsides are major pathways of plant invasions in mountain regions. However, the increasing importance of tourism may also turn hiking trails into conduits of non-native plant spread to remote mountain landscapes. Here, we evaluated the importance of such trails for plant invasion in five protected mountain areas of southern central Chile. We therefore sampled native and non-native species along 17 trails and in the adjacent undisturbed vegetation. We analyzed whether the number and cover of non-native species in local plant assemblages is related to distance
\end{abstract}

Co-last authors: Aníbal Pauchard and Stefan Dullinger.

Electronic supplementary material The online version of this article (https://doi.org/10.1007/s10530-019-02165-9) contains supplementary material, which is available to authorized users.

R. Liedtke $\cdot$ F. Essl - S. Dullinger $(\square)$

Department of Botany and Biodiversity Research,

University of Vienna, 1010 Vienna, Austria

e-mail: stefan.dullinger@univie.ac.at

R. Liedtke

e-mail: rebecca_liedtke@yahoo.com

F. Essl

e-mail: franz.ess1@univie.ac.at

\section{A. Barros}

Instituto Argentino de Nivología y Glaciologíay Ciencias, Ambientales (IANIGLA), Centro Científico y

Tecnológico (CCT), CONICET, Mendoza, Argentina

e-mail: anaagustinabarros@gmail.com to trail and a number of additional variables that characterize the abiotic and biotic environment as well as the usage of the trail. We found that non-native species at higher elevations are a subset of the lowland source pool and that their number and cover decreases with increasing elevation and with distance to trails, although this latter variable only explained $4-8 \%$ of the variation in the data. In addition, non-native richness and cover were positively correlated with signs of livestock presence but negatively with the presence of intact forest vegetation. These results suggest that, at least in the region studied, hiking trails have indeed fostered non-native species spread to higher elevations, although less efficiently than

\section{J. J. Lembrechts \\ Plants and Ecosystems Research Centre, University of Antwerp, 2610 Wilrijk, Belgium \\ e-mail: jonas.lembrechts@uantwerpen.be \\ R. E. M. Wedegärtner \\ Department of Biology, Norwegian University of Science and Technology, 7491 Trondheim, Norway \\ e-mail: ronja.e.m.wedegartner@ntnu.no}
A. Pauchard
Laboratorio de Invasiones Biológicas (LIB), Facultad de Ciencias Forestales, Universidad de Concepción,
Concepción, Chile
e-mail: pauchard@udec.cl
A. Pauchard
Institute of Ecology and Biodiversity, Santiago, Chile 
roadsides. As a corollary, appropriate planning and management of trails could become increasingly important to control plant invasions into mountains in a world which is warming and where visitation and recreational use of mountainous areas is expected to increase.

Keywords Disturbance $\cdot$ Hiking $\cdot$ Mountains $\cdot$ Nonnative plants $\cdot$ Protected areas $\cdot$ Tourism

\section{Introduction}

The distribution of non-native plant species in mountain ecosystems has received increasing attention over the last 15 years (Alexander et al. 2011, 2016; Seipel et al. 2016; Lembrechts et al. 2017; Haider et al. 2018; McDougall et al. 2018). One of the major findings of this research was that mountains are not inherently resistant to biological invasions, even though they are still less invaded than lowland regions (Guo et al. 2018). Among the factors that delay the spread of nonnative plants into mountainous areas geographical and ecological distance from the hotspots of non-native species introduction, such as harbors, cities and other hubs, play an important role (e.g. Alexander et al. 2011; Anderson et al. 2015). In the future, however, these distances may shrink, at least functionally (Alexander et al. 2016; Dainese et al. 2017). First, a warmer climate may reduce temperature constraints on the encroachment of non-specialist species into high-mountain environments (e.g. Steyn et al. 2017). Second, the further development of human infrastructure and the associated higher influx of people and commodities into mountain areas may facilitate migration of non-native species from hubs of introduction into so far remote landscapes (e.g. Chiuffo et al. 2018). Indeed, several papers have already shown that encroachment of non-native plants into mountain environments may be fostered by a warming climate (Pauchard et al. 2016; Dainese et al. 2017, Carboni et al. 2018) and is highly concentrated along the human traffic network (Seipel et al. 2012; Lembrechts et al. 2017; McDougall et al. 2018). The human infrastructure thereby facilitates non-native plant spread because, first, the associated disturbance reduces the resistance of the resident vegetation against newcomers and releases resources, and, second, traffic along this infrastructure increases the probability of propagule transport (Kalwij et al. 2008; Lembrechts et al. 2017; Haider et al. 2018).

Empirical studies on whether and how the traffic infrastructure fosters plant invasion into mountains have so far concentrated on roads with motorized traffic (Kalwij et al. 2008; Lembrechts et al. 2017; Haider et al. 2018; McDougall et al. 2018). However, tourism has nowadays become an important economic sector in many mountain regions of the world (Balmford et al. 2009). The capillary network of touristic movement in mountains consists for a critical part of recreational hiking trails, which distribute visitors to the most remote areas (Ballantyne and Pickering 2015). These trails could hence be particularly important conduits of non-native plant encroachment into pristine ecosystems. Nonetheless, few studies have tackled this issue yet, and those which have done so have provided inconsistent results (Barros and Pickering 2014; Rowe et al. 2018).

The Andes of southern Chile represent a mountain area where tourism has become economically important during the recent decades (Corporación Nacional Forestal 2018). The lowlands of this region are known to be heavily invaded (Castro et al. 2005; Figueroa et al. 2011) and non-native plant species in the area have already been shown to move to higher elevations along roads (Pauchard and Alaback 2004). However, no study has so far evaluated the distribution of nonnative species along recreational trails in the region. Here, we try to fill this gap focusing on five different protected areas spread across the central part of the southern Chilean Andes.

The importance of roads as conduits of non-native plants to higher elevations is commonly assessed by comparing the richness of non-native plants along roadsides and in adjacent undisturbed sites (Lembrechts et al. 2014, 2017; McDougall et al. 2018). Here, we transferred this approach to hiking trails. We sampled T-shaped transects perpendicular to the trails at regular intervals from their start at low elevations (henceforth called trail head) to their uppermost elevation (trail end). If the trails actually serve as pathways of ongoing non-native species spread to higher elevations, we expect that: (1) the non-native species found along the trails would be a subset of the source pool occurring in the nearby lowland areas; (2) with increasing distance from the trail head, the number of non-native species in local communities 
decreases; and (3) at each elevation, the incidence and abundance of non-native species decreases with distance to the trail. When evaluating these hypotheses, we also took into account some additional modifying factors. First, trails are sometimes also used by people on horseback and by cattle. Since domestic animals are known to be important seed dispersers (Hogan and Phillips 2011; Ansong and Pickering 2013a), we predict that the presence of domestic animals increases the abundance of nonnative species. Second, several other factors are known to affect the invasibility of a habitat, with disturbance intensity and composition of the resident vegetation particularly important (Alpert et al. 2000; Eschtruth and Battles 2009). We hence also evaluated the impact of these factors on non-native plant richness and especially focused on the role of forest versus non-forest vegetation, as forest interiors are commonly much more difficult to invade (Charbonneau and Fahrig 2004).

\section{Methods}

Study region

The study was conducted in five different protected areas (Tolhuaca National Park, Malalcahuello National Reserve, Huerquehue NP, Villarrica NP and Conguillio NP) in the region Araucanía in the south of central Chile, at elevations between 720 and $1910 \mathrm{~m}$ a.s.l. (Fig. 1). The climate in the lowlands of the region is temperate to temperate-Mediterranean and characterized by an average precipitation of $1850 \mathrm{~mm}$ and a mean annual temperature of $8.4{ }^{\circ} \mathrm{C}$ in Lonquimay $\left(\mathrm{S} 38.45500^{\circ}\right.$; $\left.\mathrm{W} 71.35583^{\circ}\right)$, Luebert and Pliscoff 2006). The main natural vegetation types are, in the lower parts, forests of Nothofagus alpina followed by $N$. dombeyi dominated forests, and forests of $N$. pumilio and Araucaria araucana up to the tree line. Above the tree line, an open alpine vegetation of herbs and grasses is widespread (Luebert and Pliscoff 2006).

The bedrock of the region consists of volcanic materials such as basalts and, in some areas, plutonic granitites (Sernageomin 2003). Three of the five protected areas (Malalcahuello, Conguillio, Villarrica) host active volcanoes, which have a strong influence on vegetation dynamics at high elevations
(Global Volcanism Program 1997, 2010, 2017). Another important disturbance factor in the region is fire (González et al. 2005). Especially Tolhuaca National Park was affected by a fire in 2015 which burned $60 \%$ of the park's area, including the area along one of the sampled trails (Gonzalez and Lara 2015). Large scale anthropogenic disturbance and the introduction of non-native species in the region of the Araucanía started relatively late as it was up until early 1900s largely territory of the indigenous Mapuche. First constant settlements of non-indigenous people in the area were founded in the late nineteenth-century (Bengoa 2000).

The protected areas Tolhuaca, Malalcahuello, Huerquehue, Villarrica and Conguillio were founded in 1935, 1931, 1967, 1940 and 1950 (Supplementary Material 1, Table 3). Prior to their foundation, extraction of wood and pasturing was important in all of the parks. Nowadays, besides ongoing forest industry and livestock farming, tourism provides an important source of income for the local population around the protected areas (Montalba and Stephens 2014). In 2017, Tolhuaca, Huerquehue, Villarrica, Conguillio, Malalcahuello were visited by $8,47,61$, 92, and 112 thousand visitors (Corporación Nacional Forestal 2018).

\section{Sampling}

Field sampling took place in January and February 2018 and (with the exception of a few details, see below) followed the Mountain Invasion Research Network (MIREN) trail survey protocol (Supplementary Material 2) which is an adaptation of the MIREN road protocol (Seipel et al. 2012). In all protected areas we sampled along officially mapped and marked trails spanning at least $200 \mathrm{~m}$ of elevation, 17 trails in total (two in Tolhuaca and Huerquehue, three in Malalcahuello and Conguillio and seven in Villarrica). The elevation of the trails varied between 717 and $1910 \mathrm{~m}$ a.s.l. Trail width varied between 40 and $350 \mathrm{~cm}$ (an overview on the trails is provided in Supplementary Material 1, Table 4).

Sampling was done in transects set up every $50 \mathrm{~m}$ of elevation, beginning at the trail head and ending at the last transect at the highest point of the trail, i.e. the trail end. Each transect consisted of three plots with a size of $2 \times 10 \mathrm{~m}$ forming a T-shape. The first plot was placed parallel to the trail in its immediate adjacency. 

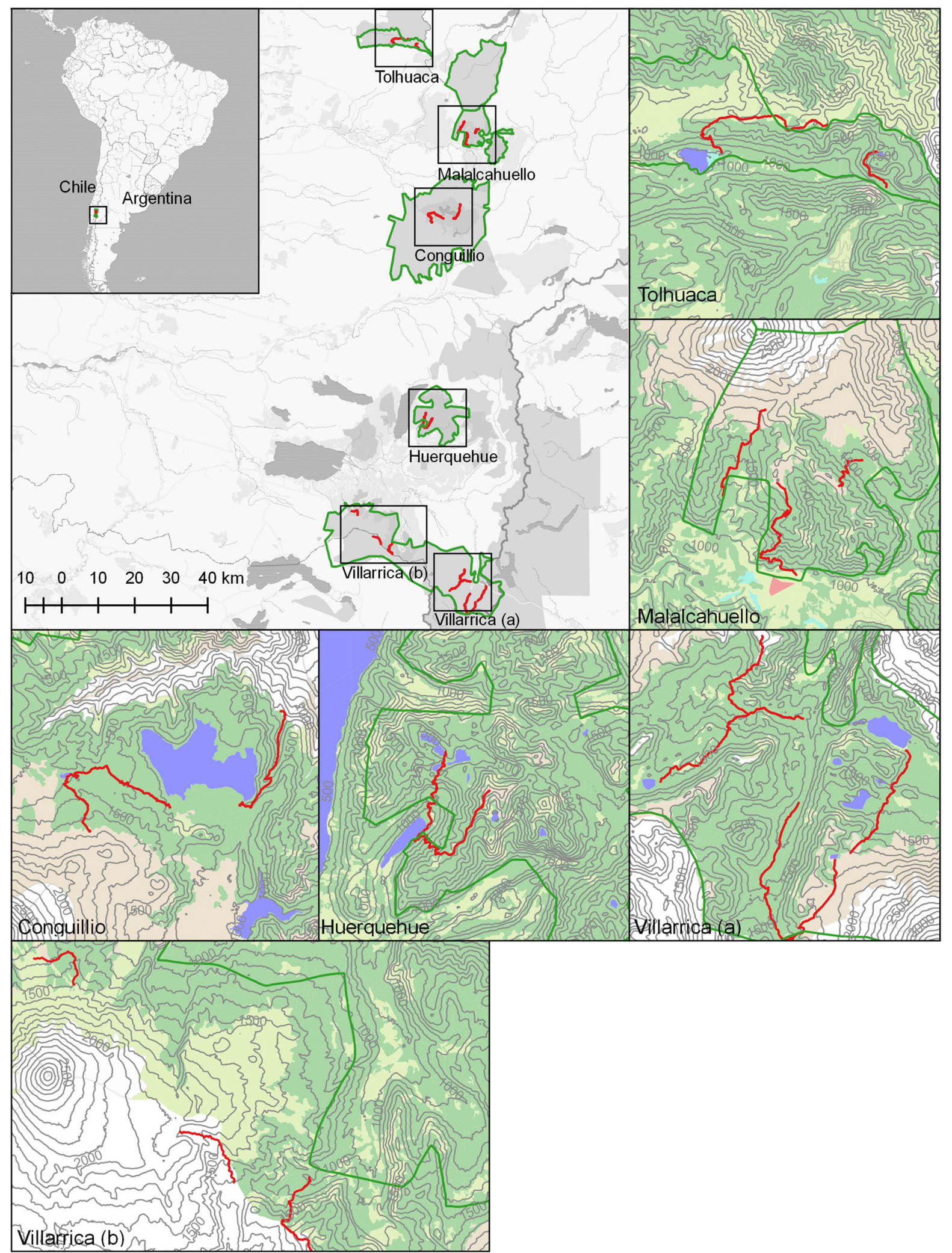
4Fig. 1 Geographical location of the study in southern Chile. Green polygons represent protected areas and red lines the sampled trails

The second plot was established at a right angle to the trail, starting in the middle of the first one, thus $2 \mathrm{~m}$ away from the trail. The third plot spanned a distance of 12-22 $\mathrm{m}$ from the trail (Supplementary Material 1, Fig. 3). We did not include the $2 \times 50 \mathrm{~m}$ plot along the trail edge in the MIREN T-trail survey scheme because this optional part of the survey is mainly thought to facilitate direct comparison of trail margins with roadsides which was not planned in our study. Moreover, omitting the $2 \times 50 \mathrm{~m}$ plots allowed us to sample a higher number of transects.

In each protected area, we additionally sampled seven to ten sites along access routes for motorized traffic, camping grounds and parking spaces at low elevations of the protected area and its adjacencies. We purposefully selected sites with high richness of non-native species as these records should serve as 'reference' sites to determine the pool of non-native species at lower elevations. We used the same transect design as along the trails. In total, we sampled 735 $10 \times 2$ m plots in 245 transects (202 along the trails and 43 in reference sites). As elevational distances between transects were fixed, transect numbers per trail varied between five and 24 (due to variation in elevational range among the trails).

In each plot of each transect, we identified all vascular plants, natives and non-natives, and estimated their ground cover at a scale from 0 to 8 $(0=0 \%, \quad 1=0-1 \%, \quad 2=2-5 \%, \quad 3=6-25 \%$, $4=26-50 \%, \quad 5=51-75 \%, \quad 6=76-95 \%$, $7=96-99 \%, 8=99-100 \%)$. This scale follows the MIREN survey protocol for roads (see e.g. Seipel et al. 2012) and accounts for the fact that observers tend to visually estimate extreme cover values more accurately than intermediate ones. Finer differentiation of low cover values is moreover useful when species, as the non-natives in the case of this study, are rare in almost all plots because it allows for a finer differentiation of the predominant low cover values. Additionally, we estimated the percentage cover of forest, of overall vegetation and of bare soil at the same scale and recorded the exact location, elevation and the walking distance from the trail head with a hand-held GPS-receiver. We further collected data on the trail width (in meters, as an indicator of disturbance intensity) and recorded the presence or absence of dung of domestic herbivores (i.e. cows and horses) as an indicator of trail use by such animals.

We classified the plant species recorded as native or non-native following the database of the Darwinian Institute (Instituto de Botánica Darwinion 2018; Fuentes et al. 2013).

Analyses

All analyses were conducted in $\mathrm{R}$ ( $\mathrm{R}$ Core Team 2018).

We evaluated how complete we had sampled the regional lowland pool of non-native species along our reference site transects. We therefore used the firstorder jackknife formula implemented in the specpool function of the vegan package (Oksanen et al. 2018). The formula estimates extrapolated species richness, and hence the number of species present but not observed, using the number of samples (= plots in this case) and the number of rare species in the observed pool as input parameters. The method provides a lower boundary of the true species pool size rather than an unbiased estimate (Chiu et al. 2014).

We used three different metrics to characterize the contribution of non-native plants to the communities sampled in each plot: (1) number of non-native species, (2) ratio of non-native and total species numbers (non-native/total richness), and (3) ratio of non-native species cover to total vegetation cover (non-native/total cover). The non-native/total species richness was calculated to account for differences in native species richness among sites, especially along the elevational gradient. We included the non-native/total cover as this metric may be particularly informative for the non-native species' impact on the local plant community (Vilà et al. 2011). We calculated the non-native/total cover after transformation of the rank-scaled cover values sampled to the median percent cover values in each rank ("0", " 1 ", “2", "3", "4", "5", "6", "7", and "8" to $0 \%, 0.5 \%, 3 \%, 15 \%$, $37.5 \%, 62.5 \%, 85 \%, 97 \%$, and $99.5 \%$ ).

To test the hypotheses about the decrease of nonnative species with increasing horizontal distance from the trail and from the lowland trail head we correlated the three different metrics to the respective data sampled: (1) namely a plot's distance from the trail edge (henceforth called distance to trail), (2) its 
walking distance from the trail head, and (3) its elevation. Distance to trail was thereby indicated by plot number within T-transect (1-immediately adjacent plot, 2-intermediate plot, 3-plot farthest away from the trail), thus implicitly linearizing an assumed non-linear distance decay. We further included four additional predictor variables in our analyses which should account for differential invasibility of resident communities, trail use intensity, and trail usage by livestock. With respect to invasibility we used forest cover (in percent as above; cf. Charbonneau and Fahrig 2004) and native species composition of resident communities, indicated by the first two axes of a PCA run on the percentage cover values of all native species in all plots (prcomp function in $\mathrm{R}$, cf. Supplementary Material, Fig. 4). For indicating intensity of use and livestock usage, we used trail width and the presence or absence of domestic animal dung. The metric predictors (transect elevation, distance from trail head, distance to trail, forest cover, PCA1, PCA2, and trail width) were scaled to a mean of zero and a standard deviation of one to make coefficients of the subsequent regression directly comparable.

Response and predictor variables were correlated by means of generalized linear mixed effects models using the glmer function of the lme4 package in $\mathrm{R}$ (Bates et al. 2015). We assumed a Poisson family distribution and used the standard log-link function to model non-native species richness. For models of nonnative/total richness and cover ratios we used a binomial distribution of the response with a logit-link function. Among predictor variables, distance to trail was included in all models. Elevation and distance from trail head were highly correlated with each other and could hence not be combined in one model. We thus ran separate bi-variate models with only one of these two variables (and distance to trail) included, and then continued the analysis with the model that had the lower Akaike Information Criterion (AIC). We added the remaining predictors (trail width, forest cover, and presence of dung) to this model, first alone and then in all possible combinations of two. Only the two PCA axes were just added as a pair and not as separate variables because they conceptually characterize only one feature of the sampled plots (native species composition). We could not account for more than four predictors in a model simultaneously as parameter estimation procedures failed to converge with more complex models. We used nested random factors for protected area, trail and transect identity in all models. To test for possible overdispersion we used the dispersion_glmer function of the blmeco package in R (Korner-Nievergelt et al. 2015). For all models, we checked for possible bias due to collinearity of predictor variables by calculating variance inflation factors by means of the vif function of the car package in R (Fox and Weisberg 2011). No critical collinearity or overdispersion was detected.

We compared candidate models, with distance to trail, elevation or distance from trail head and all combinations of additional predictor variables, as described above, by means of the Akaike Information Criterion (AIC). Of the model with the lowest AIC, we calculated the conditional $\mathrm{R}^{2}$ using the R.squared.GLMM function of the MuMIn package (Barton 2018). For information on the variance explained by fixed effects we calculated the marginal $\mathrm{R}^{2}$-values with the $r 2$ beta function of the $r 2 \mathrm{glmm}$ package using the standardized generalized variance approach (Jaeger et al. 2017). We explored the relative contribution of individual fixed-effect predictors to marginal $\mathrm{R}^{2}$ values of the best multiple regression models by comparison with univariate models.

\section{Results}

We sampled 46 non-native species in the lowland reference plots and 40 non-native species along the trails. Extrapolating the lower boundary of real species richness in the lowland source pool from the reference plots resulted in an estimated lowland pool size of 53 non-native species. This is exactly the number of nonnative species that we sampled in total, i.e. in the reference and trail plots in combination. As a corollary, seven species were only found along the trails but not in the lowland reference plots (Malalcahuello: 7 of 28, Conguillio: 1 of 2, Tolhuaca and Huerquehue: 2 of 17, and in Villarrica: 4 of 22). The average non-native cover in the plots was $6.7 \%$. The most commonly found non-native species were Rumex acetosella, Hypochaeris radicata, Taraxacum officinale and Agrostis capillaris. A list of all non-native species found along the trails, together with their frequency and their average cover is provided in the Supplementary Material 1 (Table 5). In addition to the non-native species we found 192 native species along the trails. 
Five additional taxa, all of them rare, could not be identified to species level.

Which factors influence the distribution of nonnative species along mountain trails?

Non-native species richness and the non-native/total richness ratio were best explained by a model with elevation, distance to trail, forest cover, and presence of livestock dung as predictors (Table 1, Fig. 2). Including elevation into the model generally resulted in better predictions of non-native species richness than including distance from the trail head. The addition of dung presence, forest cover and trail width improved model fit in all cases, with forest cover having a particularly strong impact on AICs. As models including trail width had higher AIC values than models including dung and forest cover, trail width was not included in the final (four-predictor) model.

The first two axes of a PCA of the native species cover in the recorded plots together explained $46 \%$ of the variance. The three most important species influencing the PCA axes were the trees Nothofagus dombeyi and Nothofagus pumilio and the bamboo Chusquea quila (Supplementary Material, Fig. 4). All three of these species are negatively correlated with one or both PCA axes. For non-native species richness and the non-native/total richness ratio, a model including these two axes as predictors in addition to elevation and distance to trail had a slightly higher AIC-value than the abovementioned best model including forest cover and dung instead. For nonnative/total cover, in contrast, the model with PCA1 and PCA 2 in addition to elevation and distance to trail was the one with the lowest AIC.

The effects of variables were consistent across all models which included the respective predictor: for all three metrics used, non-native species contribution to the vegetation of the recorded plots decreased with increasing elevation and increasing distance from the trail. Non-native species richness and the non-native/total richness decreased with forest cover and increased with presence of livestock dung. Nonnative/total cover increased non-linearly along the PCA1 and PCA2 of native species composition (Fig. 2) and hence was negatively correlated with the abundance of Nothofagus dombeyi, Nothofagus pumilio and Chusquea quila in particular.

Conditional $\mathrm{R}^{2}$-values varied between 0.56 and 0.7 , and marginal $\mathrm{R}^{2}$-values between 0.21 and 0.28 for the three models (Table 2). Contributions of individual predictor variables to marginal $\mathrm{R}^{2}$-values were relatively consistent across response metrics. Elevation explained between 43 and $62 \%$ of the variance, distance to trail between 4 and $8 \%$. Forest cover was highly important in the models of absolute and relative non-native species richness, explaining $\sim 50 \%$ of the

Table 1 AIC values of generalized linear mixed effects models for non-native plant species richness, the non-native/total richness ratio, and the non-native/total cover ratio in vegetation plots sampled along hiking trails in southern central Chile

\begin{tabular}{llll}
\hline Predictors & $\begin{array}{l}\text { Non-native } \\
\text { species richness }\end{array}$ & $\begin{array}{l}\text { Non-native/total } \\
\text { richness }\end{array}$ & $\begin{array}{l}\text { Non-native/total } \\
\text { cover }\end{array}$ \\
\hline Distance trail head + distance trail & 1349.2 & 1213.9 & 2305.4 \\
Elevation + distance trail & 1340.1 & 1204.2 & 2295.7 \\
Elevation + trail width + distance trail & 1334.7 & 1197.6 & 2290.8 \\
Elevation + dung + distance trail & 1332.9 & 1196.3 & 2288.9 \\
Elevation + forest cover + distance trail & 1261.0 & 1116.6 & 2191.9 \\
Elevation + trail with + dung + distance trail & 1331.9 & 1194.2 & 2290.2 \\
Elevation + forest cover + trail width + distance trail & 1256.8 & 1110.8 & 2187.3 \\
Elevation + PCA1 + PCA2 + distance trail & 1256.2 & 1125.8 & $\mathbf{2 0 5 2 . 9}$ \\
Elevation + forest cover + dung + distance trail & $\mathbf{1 2 5 3 . 9}$ & $\mathbf{1 1 0 7 . 7}$ & 2184.4
\end{tabular}

Only models with up to four predictors could be fitted. Distance to trail was included in all models. Elevation generally outperformed distance from trail head in otherwise identical models and these alternative models are hence only represented for the case of the most simple model structure (i.e. in combination with Distance to trail). The AIC of best models is indicated by bold font 

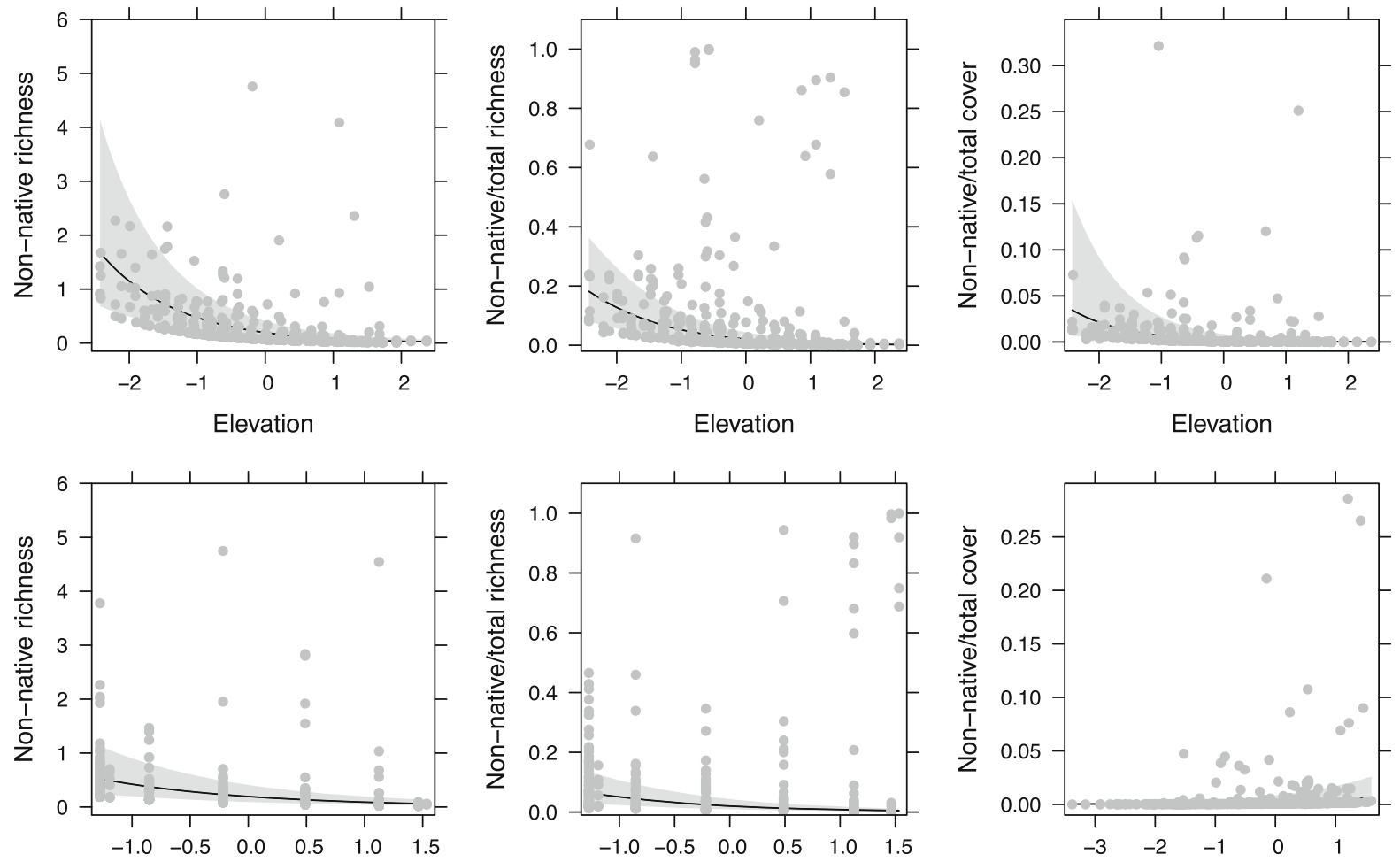

Forest cover
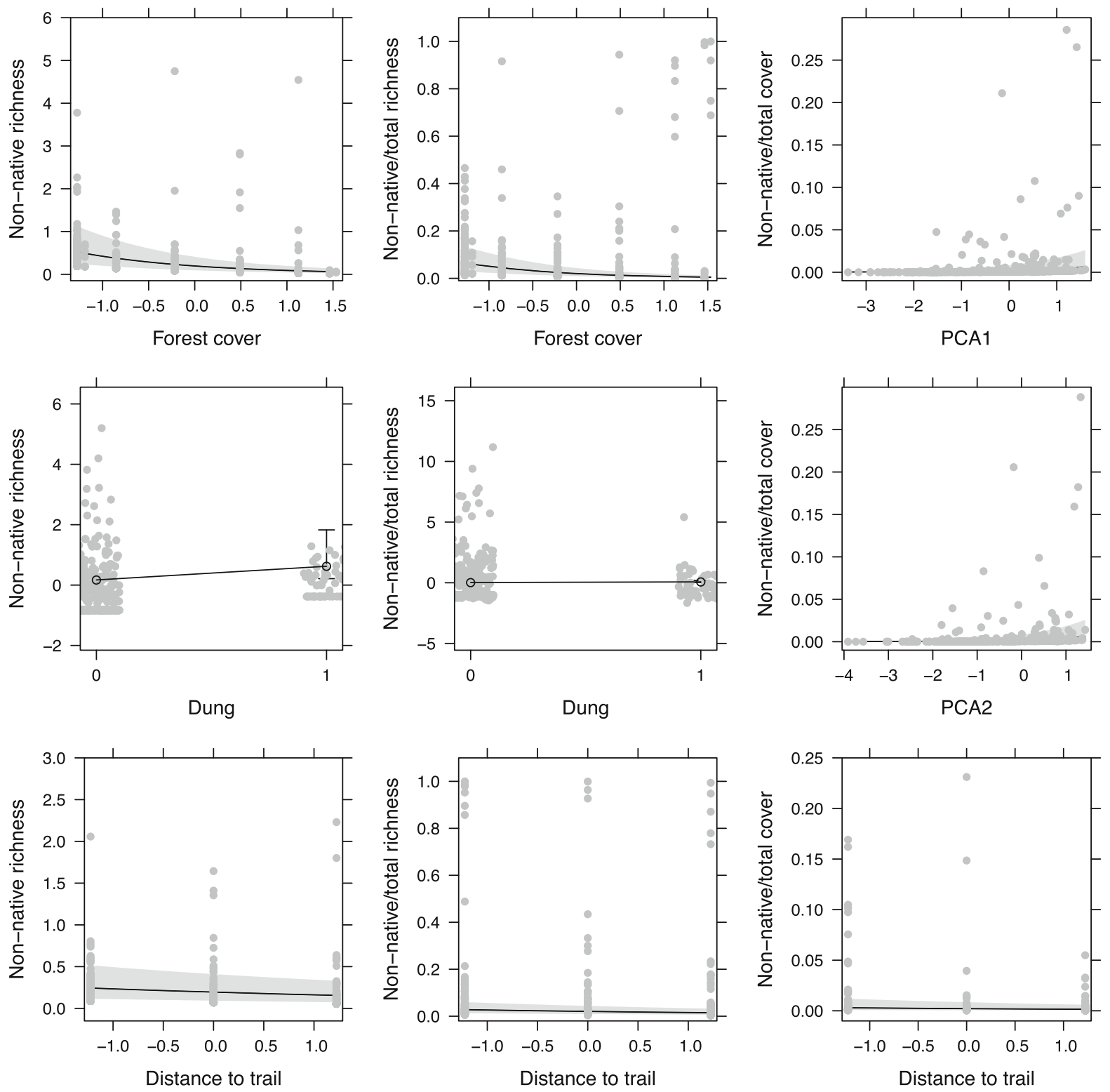
4Fig. 2 Partial effect plots of scaled (mean of zero and standard deviation of one) fixed-effects predictor variables in the best fitting models (cf. Table 1) of non-native plant species richness, the non-native/total richness ratio, and the non-native/total cover ratio in vegetation plots sampled along hiking trails in southern central Chile. Points represent the plots sampled, shaded areas around regression lines their $0.95 \%$ confidence intervals. Position of points on the y-axis is equal to the partial fit (position on the regression line) plus the corresponding residual. Plots were drawn with the effects library in R (Fox and Weisberg 2018)

variance, while presence of dung explained $16 \%$ of the variance. In the model of non-native/total cover, the two PCA-axes together contributed about $60 \%$ to marginal $\mathrm{R}^{2}$ (Table 2).

\section{Discussion}

Hiking trails a conduits of plant invasions

Barros and Pickering (2014) has already discussed that hiking infrastructure may facilitate non-native species spread to higher elevations of the Andes by channeling both propagule transport and human disturbance in these mostly pristine areas. Here, we put this idea to a more systematic test. We expected that if hiking trails actually play such a role, (1) the non-native species along the trails should be a subset of the lowland source pool (2) the frequency of non-native species should be a function of distance from trail head or

Table 2 Marginal and conditional $\mathrm{R}^{2}$-values of the best models (selected via AIC, cf. Table 1) for non-native plant species richness, the non-native/total richness ratio, and the

\begin{tabular}{llll}
\hline & Non-native species richness & Non-native/total richness & Non-native/total cover \\
\hline Marginal $\mathrm{R}^{2}$ & 0.24 & 0.28 & 0.21 \\
Conditional $\mathrm{R}^{2}$ & 0.65 & 0.56 & 0.7 \\
Elevation & $0.14(61 \%)$ & $0.17(61 \%)$ & $0.09(44 \%)$ \\
Distance to trail & $0.01(4 \%)$ & $0.02(8 \%)$ & $0.02(9 \%)$ \\
Forest cover & $0.12(50 \%)$ & $0.14(51 \%)$ & $0.08(39 \%)$ \\
Dung & $0.04(17 \%)$ & $0.04(15 \%)$ & $0.05(22.5 \%)$ \\
PCA 2 & & & \\
PCA 1 & & & \\
\hline
\end{tabular}

The contribution of the individual fixed effects to marginal $\mathrm{R}^{2}$-values was assessed by comparison with the respective univariate models. Note that the sum of contributions may be $>100 \%$ because part of the variance explained by the multiple model may be shared among two or more predictor variables elevation, and (3) at each elevation, non-native species should become rarer with increasing distance from the trail margin. Our results corroborate all three of these expectations and hence support the idea that trails serve as conduits of plant invasion into mountainous areas, at least in the region studied. They also indicate, however, that the efficiency of these conduits is relatively moderate.

Classifying the role of hiking trails for plant invasions into mountains as only moderate is motivated by the comparison of our results with equivalent findings along mountain roads, especially with respect to how the incidence and abundance of non-native species relates to proximity to these infrastructures. In a global analysis, Seipel et al. (2012) have shown that in a model with elevation and distance from roads as predictors of non-native species numbers, distance from road accounted for $11 \%$ of the variation. In the models fit with our data, the equivalent variable, distance from the trail only explained between 4 and $8 \%$ of the variation. In other words, road margins contrast more clearly with the surrounding vegetation in terms of non-native species numbers than trail margins do. Trails may be less conducive to invasions for several reasons: first, hikers transport less seeds than vehicle traffic (Pickering and Mount 2010; Ansong and Pickering 2013a), and frequency of usage is lower, so that, in general both the likelihood and the number of dispersed propagules are lower. Second, natural vegetation is less intensively disturbed during construction and subsequent use of hiking trails, and

non-native/total cover ratio in vegetation plots sampled along hiking trails in southern central Chile 
the total area affected by these disturbances is smaller (Ballantyne and Pickering 2015). In particular, forest cover, which is also an important barrier to non-native colonization in our data, is not necessarily reduced by trails and may hence impede non-native species establishment even immediately adjacent to the trail. Third, in contrast to roads, most trails are constructed without adding material from distant sources such as gravel or sand (Newsome et al. 2013), which can contain seeds of non-native plants and potentially mediate their rapid dispersal from lower elevations. Finally, it may also be that non-native species are regionally less dependent on the human traffic infrastructure and associated disturbances because the native vegetation away from the trail is more invasible than in other parts of the world. Indeed, McDougall et al. (2018) reported that in Chile an unusually high proportion of non-native species from roadside plots is also present in the adjacent vegetation (see also Seipel et al. 2012). Reasons for this peculiarity are unclear but may include livestock grazing by domestic cattle which is widespread in the region (Pauchard and Alaback 2004, see below).

\section{Directional ecological filtering}

With a few exceptions, the species we found along the trails also occurred in the source pool reference plots at lower elevations. In addition, elevation explained most of the variance in richness and cover of nonnative species in our data. These results mirror similar findings in the eastern Himalaya (Yang et al. 2018) and suggest that the major pathway of non-native species flow into the regional mountain areas goes via initial establishment in nearby lowlands, and subsequent spreading to higher elevations, e.g. as stowaways in the clothes, shoes or other mountaineering equipment of hikers (Whinam et al. 2005; Pickering and Mount 2010). Direct transport from one mountain to the other is apparently rare (Lembrechts et al. 2017). A decrease in non-native richness with elevation has been observed in many other studies and may have different reasons (Pauchard et al. 2009; Alexander et al. 2016; Steyn et al. 2017). First, both disturbance frequency and/or intensity and propagule pressure may decrease with increasing elevation due to lower human visitation frequency and/or sequential depletion of transported propagules. The elevational structure of non-native species distribution would hence mainly emerge because species need longer to arrive and establish at higher elevations, thus representing a non-equilibrium situation (cf. Kalwij et al. 2015). Second, climate gets harsher at higher elevations and hence likely filters species not able to withstand these conditions. As a corollary, the elevational structure would be driven by differences of species' niches, representing an equilibrium situation (e.g. Steyn et al. 2017) which will, nevertheless, gradually change with climate warming (e.g. Rumpf et al. 2018). In our case, we assume that disturbance intensity from hiking is relatively similar along the entire length of the trails, as tourists usually hike the whole trail from start to finish. Moreover, trail width (a proxy for disturbance intensity) had only a comparatively low effect on nonnative species distribution in our data in general. The relative impacts of climate versus propagule pressure are harder to disentangle. However, the fact that models including elevation explained non-native richness and cover better than models including distance from the trail head suggests that climate filtering does play a role. In addition, an exploratory analysis of Ellenberg indicator values (Ellenberg et al. 2010) of the subset of the non-native species with European origin (46 out of 53 non-native species in total) indicated that higher elevation plots tend to harbor species better adapted to cold conditions (results not shown). Quantifying the magnitude of this climatic effect in comparison with decreasing propagule pressure is, however, impossible with our data. Proper evaluation of this question requires experimental manipulation of propagule input (Lembrechts et al. 2016).

Other factors modifying non-native species distribution

As expected, the number and cover of non-native species in our data did not only depend on distance to trails and elevation, but was also affected by two additional factors: the presence of livestock, and the structure and composition of native plant communities. Like humans, domestic animals can serve as dispersal vector of non-native plant propagules (Hogan and Phillips 2011; Ansong and Pickering 2013b). Additionally, livestock grazing is an important disturbance factor that can considerably increase the invasibility of native plant communities (Hobbs 2001). A positive impact of domestic animals on 
non-native plant occurrence and abundance has indeed already been reported in several studies (Chaneton et al. 2002; Parker 2006; Barros and Pickering 2014). Our own results are in line with these earlier findings: presence of livestock dung was positively correlated with the number of non-native species in the plots. Clarifying whether this correlation is rather due to the role of livestock as dispersal vector or as disturbance agent would again need targeted experimentation. However, as presence of dung is more strongly associated with non-native species numbers than distance to trail or trail width, our primary disturbance indicators, we suppose that transport of propagules by the animals is at least contributing to the relationship found.

In our models, the factor most strongly correlated with non-native species numbers, apart from elevation, was forest cover. Forest cover includes information on both the type of resident vegetation and, implicitly, on human or natural disturbance regimes. In the study area, the natural vegetation is supposed to be a mixed Nothofagus forest at low elevations, followed upslope by more open forests including Araucaria, and, finally, alpine vegetation above the timberline (Gajardo 1995). However, natural disturbance regimes, and in particular fire, constrain regional forest distribution (Veblen et al. 2008). In addition, the natural forests have partly been replaced by grasslands as a result of livestock grazing (Armesto 1998). Like in other mountain regions across the world (Pauchard et al. 2009), these disturbed and open areas, and especially the pastured grasslands, are now preferentially invaded by non-native species. Many of these non-native species are bound to meadows, pasture and other open vegetation in their native range (often Europe), too (Ellenberg et al. 2010). Hence they cannot cope well with the low light availability in intact Nothofagus or Araucaria forests. In addition, principal components of native species composition were related to non-native species cover. The native species most pronouncedly affecting the PCA and negatively correlated to non-native cover, Chusquea quila (a masting bamboo species), N. pumilio and $N$. dombeyi, are all indicators of intact natural forests. This result hence re-enforces the resistance of such forests to non-native species encroachment.

\section{Regional differences}

According to marginal $\mathrm{R}^{2}$-values our fixed effect predictors only explained $20-30 \%$ of the variation in non-native species richness and cover in our data. This moderate value may be due in part to measurement errors caused, for example, by the horizontal and vertical inaccuracy of hand-held GPS measurements, and hence elevation and distance from trail head values of individual sampling plots. However, the conditional $\mathrm{R}^{2}$-values (describing the variation explained by the fixed and the random factors, i.e. protected area, trails and transects) reached up to $70 \%$, suggesting that macro- to microscale geographical variation was a main determinant of the differences in non-native species numbers and abundance in our data. Differences among protected areas may be the result of distinct landscape history, i.e. historical uses of the areas, the time passed since the protected area was established, and differences in management effort and efficiency. For trail identity, intensity of usage and the kind of use (hiking, horseback riding, mountain biking) may be as important as the distance from potential source pools in explaining the incidence and frequency of non-native plants (cf. e.g. Barros and Pickering 2014). Detailed information on these factors is, however, rarely available, and their relative effects hence had to remain pooled under 'random effects' in our models.

\section{Conclusions}

Our results indicate that a considerable number of nonnative species has already colonized the montane protected areas of southern central Chile. Even if their impact does not equal the one of roads, hiking trails obviously played a role for their spread, especially if they were also used by livestock or pack animals. The contribution of non-native species to total vegetation cover is still low, especially at higher elevations, probably because some species are filtered by the harsher climatic conditions and others have not yet reached their potential distribution. With ongoing climate warming we can expect that both of these species groups will expand their regional ranges upward in the future as has already been shown in other mountain environments (Dainese et al. 2017; Lembrechts et al. 2017). Hiking trails will likely 
continue to play a role as driver of this spread, especially as the number of mountaineers will probably further increase (Balmford et al. 2009). However, our results suggest that the way these trails are constructed and used can lower their efficiency as invasion conduits. In particular, trail construction could make use of the potential barrier effect that intact natural forests have on non-native plant spread, and the exclusion of domestic animals, either as livestock or as means of transport, could reduce both propagule pressure and disturbance related establishment odds. These measures may not fully prevent invasion, yet they will likely reduce the rate by which non-native plants will encroach into the still pristine mountain environments of southern Chile.

Acknowledgements Open access funding provided by University of Vienna. AP was funded by Fondecyt 1180205 and CONICYT PIA AFB17008.

Open Access This article is distributed under the terms of the Creative Commons Attribution 4.0 International License (http:// creativecommons.org/licenses/by/4.0/), which permits unrestricted use, distribution, and reproduction in any medium, provided you give appropriate credit to the original author(s) and the source, provide a link to the Creative Commons license, and indicate if changes were made.

\section{References}

Alexander JM, Kueffer C, Daehler CC, Edwards PJ, Pauchard A, Seipel T, MIREN Consortium (2011) Assembly of nonnative floras along elevational gradients explained by directional ecological filtering. Proc Natl Acad Sci 108:656-661. https://doi.org/10.1073/pnas.1013136108

Alexander JM, Lembrechts JJ, Cavieres LA, Daehler C, Haider S, Kueffer C, Liu G, McDougall K, Milbau A, Pauchard A, Rew LJ, Seipel T (2016) Plant invasions into mountains and alpine ecosystems: current status and future challenges. Alp Bot 126:89-103. https://doi.org/10.1007/ s00035-016-0172-8

Alpert P, Bone E, Holzapfel C (2000) Invasiveness, invasibility and the role of environmental stress in the spread of nonnative plants. Perspect Plant Ecol Evol Syst 3:52-66. https://doi.org/10.1078/1433-8319-00004

Anderson LG, Rocliffe S, Haddaway NR, Dunn AM (2015) The role of tourism and recreation in the spread of non-native species: a systematic review and meta-analysis. PLoS ONE 10:e0140833

Ansong M, Pickering C (2013a) Are weeds hitchhiking a ride on your car? A systematic review of seed dispersal on cars. PLoS ONE 8:e80275. https://doi.org/10.1371/journal. pone. 0080275
Ansong M, Pickering C (2013b) A global review of weeds that can germinate from horse dung. Ecol Manag Restor 14:216-223. https://doi.org/10.1111/emr.12057

Armesto JJ (1998) Conservation targets in South American temperate forests. Science 282:1271-1272. https://doi.org/ $10.1126 /$ science.282.5392.1271

Ballantyne M, Pickering CM (2015) The impacts of trail infrastructure on vegetation and soils: current literature and future directions. J Environ Manag 164:53-64. https://doi. org/10.1016/j.jenvman.2015.08.032

Balmford A, Beresford J, Green J, Naidoo R, Walpole M, Manica A (2009) A global perspective on trends in naturebased tourism. PLoS Biol 7:e1000144. https://doi.org/10. 1371/journal.pbio.1000144

Barros A, Pickering CM (2014) Non-native plant invasion in relation to tourism use of Aconcagua Park, Argentina, the highest protected area in the Southern Hemisphere. Mt Res Dev 34:13-26. https://doi.org/10.1659/MRD-JOURNALD-13-00054.1

Barton K (2018) MuMIn: multi-model inference. R package version 1.42.1. https://CRAN.R-project.org/package $=$ MuMIn. Accessed 10 May 2018

Bates D, Mächler M, Bolker B, Walker S (2015) Fitting linear mixed-effects models using lme4. J Stat Softw. https://doi. org/10.18637/jss.v067.i01

Bengoa J (2000) Historia del pueblo mapuche (siglo XIX y XX). Lom Ediciones, Santiago

Carboni M, Gueguen M, Barros C, Georges D, Boulangeat I, Douzet R, Dullinger S, Klonner G, van Kleunen M, Essl F, Bossdorf O, Haeuser E, Talluto MV, Moser D, Block S, Dullinger I, Munkemuller T, Thuiller W (2018) Simulating plant invasion dynamics in mountain ecosystems under global change scenarios. Glob Change Biol 24:e289-e302. https://doi.org/10.1111/gcb.13879

Castro SA, Figueroa JA, Muñoz-Schick M, Jaksi FM (2005) Minimum residence time, biogeographical origin, and life cycle as determinants of the geographical extent of naturalized plants in continental Chile. Divers Distrib 11:183-191. https://doi.org/10.1111/j.1366-9516.2005. 00145.x

Chaneton EJ, Perelman SB, Omacini M, Leon RJC (2002) Grazing, environmental heterogeneity, and alien plant invasions in temperate Pampa grasslands. Biol Invasions 4:7-24. https://doi.org/10.1023/A:1020536728448

Charbonneau NC, Fahrig L (2004) Influence of canopy cover and amount of open habitat in the surrounding landscape on proportion of alien plant species in forest sites. Écoscience 11:278-281. https://doi.org/10.1080/11956860.2004. 11682833

Chiu CH, Wang YT, Walther BA, Chao A (2014) Improved nonparametric lower bound of species richness via a modified Good-Turing frequency formula. Biometrics 70:671-682

Chiuffo MC, Cock CM, Prina AO, Hierro JL (2018) Response of native and non-native ruderals to natural and human disturbance. Biol Invasions 20:2915-2925. https://doi.org/10. 1007/s10530-018-1745-9

Corporación Nacional Forestal (2018) Estadistica Visitantes Unidad SNAPSE para el Año: 2017. http://www.conaf.cl/ wp-content/files_mf/1522175651Totalvisitantes2017.pdf. Accessed 23 Sept 2018 
Dainese M, Aikio S, Hulme PE, Bertolli A, Prosser F, Marini L (2017) Human disturbance and upward expansion of plants in a warming climate. Nat Clim Change 7:577-580. https:// doi.org/10.1038/nclimate3337

Ellenberg H, Leuschner C, Dierschke H (2010) Vegetation Mitteleuropas mit den Alpen. Ulmer, Stuttgart

Eschtruth AK, Battles JJ (2009) Assessing the relative importance of disturbance, herbivory, diversity, and propagule pressure in exotic plant invasion. Ecol Monogr 79:265-280. https://doi.org/10.1890/08-0221.1

Figueroa JA, Teillier S, Castro SA (2011) Diversity patterns and composition of native and exotic floras in central Chile. Acta Oecol 37:103-109. https://doi.org/10.1016/j.actao. 2011.01.002

Fox J, Weisberg S (2011) An R companion to applied regression, 2nd edn. Sage, Thousand Oaks

Fox J, Weisberg S (2018) Visualizing fit and lack of lit in complex regression models with predictor effect plots and partial residuals. J Stat Softw 87:1-27. https://doi.org/10. 18637/jss.v087.i09

Fuentes N, Pauchard A, Sánchez P, Esquivel J, Marticorena A (2013) A new comprehensive database of alien plant species in Chile based on herbarium records. Biol Invasions 15:847-858. https://doi.org/10.1007/s10530-012-0334-6

Gajardo R (1995) La vegetación natural de Chile: clasificación y distribución geográfica, 2nd edn. Univ. Santiago de Chile, Santiago

Global Volcanism Program (1997) Report on Lonquimay (Chile). In: Wunderman R (ed) Bulletin of global volcanism network, vol 22. Smithsonian Institution, Washington, p 3

Global Volcanism Program (2010) Report on Llaima (Chile). In: Wunderman R (ed) Bulletin of the global volcanism network, vol 35. Smithsonian Institution, Washington, p 6

Global Volcanism Program (2017) Report on Villarrica (Chile). In: Venzke E (ed) Bulletin of global volcanism network, vol 42. Smithsonian Institution, Washington, p 12

Gonzalez ME, Lara A (2015) Large fires in the Andean Araucaria forests: when a natural ecological pro cess becomes a threat. Conserv News 49:394

González ME, Veblen TT, Sibold JS (2005) Fire history of Araucaria-Nothofagus forests in Villarrica National Park, Chile: fire history of Araucaria-Nothofagus forests. J Biogeogr 32:1187-1202. https://doi.org/10.1111/j.1365-2699. 2005.01262.x

Guo Q, Fei S, Shen Z, Iannone BV III, Knott J, Chown SL (2018) A global analysis of elevational distribution of nonnative versus native plants. J Biogeogr 45:793-803. https:// doi.org/10.1111/bji.13145

Haider S, Kueffer C, Bruelheide H, Seipel T, Alexander JM, Rew LJ, Arévalo JR, Cavieres LA, McDougall KL, Milbau A, Naylor BJ, Speziale K, Pauchard A (2018) Mountain roads and non-native species modify elevational patterns of plant diversity. Glob Ecol Biogeogr 27:667-678. https:// doi.org/10.1111/geb.12727

Hobbs RJ (2001) Synergisms among habitat fragmentation, livestock grazing, and biotic invasions in Southwestern Australia. Conserv Biol 15:1522-1528. https://doi.org/10. 1046/j.1523-1739.2001.01092.x
Hogan JP, Phillips CJC (2011) Transmission of weed seed by livestock: a review. Anim Prod Sci 51:391-398. https://doi. org/10.1071/AN10141

Instituto de Botánica Darwinion (2018) Online Flora Database. http://www.darwin.edu.ar/Proyectos/FloraArgentina/fa. htm. Accessed 12 July 2018

Jaeger BC, Edwards LJ, Das K, Sen PK (2017) An $R^{2}$ statistic for fixed effects in the generalized linear mixed model. J Appl Stat 44:1086-1105. https://doi.org/10.1080/ 02664763.2016.1193725

Kalwij JM, Robertson MP, van Rensburg BJ (2008) Human activity facilitates altitudinal expansion of exotic plants along a road in montane grassland, South Africa. Appl Veg Sci 11:491-498. https://doi.org/10.3170/2008-7-18555

Kalwij JM, Robertson MP, van Rensburg BJ (2015) Annual monitoring reveals rapid upward movement of exotic plants in a montane ecosystem. Biol Invasions 17:3517-3529. https://doi.org/10.1007/s10530-015-09753

Korner-Nievergelt F, Roth T, von Felten S, Guelat J, Almasi B, Korner-Nievergelt P (2015) Bayesian data analysis in ecology using R, BUGS and Stan. Elsevier, New York

Lembrechts JJ, Milbau A, Nijs I (2014) Alien roadside species more easily invade alpine than lowland plant communities in a subarctic mountain ecosystem. PLoS ONE 9:e89664. https://doi.org/10.1371/journal.pone.0089664

Lembrechts JJ, Pauchard A, Lenoir J, Nuñez MA, Geron C, Ven A, Bravo-Monasterio P, Teneb E, Nijs I, Milbau A (2016) Disturbance is the key to plant invasions in cold environments. Proc Natl Acad Sci 113:14061-14066. https://doi. org/10.1073/pnas.1608980113

Lembrechts JJ, Alexander JM, Cavieres LA, Haider S, Lenoir J, Kueffer C, McDougall K, Naylor BJ, Nuñez MA, Pauchard A, Rew LJ, Nijs I, Milbau A (2017) Mountain roads shift native and non-native plant species' ranges. Ecography 40:353-364. https://doi.org/10.1111/ecog.02200

Luebert F, Pliscoff P (2006) Sinopsis bioclimática y vegetacional de Chile. Editorial Universitaria, Santiago de Chile

McDougall KL, Lembrechts JJ, Rew LJ, Haider S, Cavieres LA, Kueffer C et al (2018) Running off the road: roadside nonnative plants invading mountain vegetation. Biol Invasions 20:3461-3473. https://doi.org/10.1007/s10530-018-1787$\mathrm{Z}$

Montalba R, Stephens N (2014) Ecological change and the "Ecological Mapuche": a historical sketch of the human ecology of Chile's Araucania region. Hum Ecol 42:637-643. https://doi.org/10.1007/s10745-014-9678-0

Newsome D, Moore SA, Dowling RK (2013) Natural area tourism: ecology, impacts, and management. Aspects of tourism, vol 58, 2nd edn. Channel View Publications, Bristol

Oksanen J, Guillaume Blanchet F, Friendly M, Kindt R, Legendre P, McGlinn D, Minchin P, O’Hara RB, Simpson GL, Solymos P, Stevens MHH, Szoecs E, Wagner H (2018) vegan: community ecology package. $\mathrm{R}$ package version 2.5-2. https://CRAN.R-project.org/package=vegan. Accessed 21 May 2018

Parker JD (2006) Opposing effects of native and exotic herbivores on plant invasions. Science 311:1459-1461. https:// doi.org/10.1126/science. 1121407 
Pauchard A, Alaback PB (2004) Influence of elevation, land use, and landscape context on patterns of alien plant invasions along roadsides in protected areas of South-Central Chile. Conserv Biol 18:238-248. https://doi.org/10.1111/j.15231739.2004.00300.x

Pauchard A, Kueffer C, Dietz H, Daehler CC, Alexander J, Edwards PJ, Arévalo JR, Cavieres LA, Guisan A, Haider S, Jakobs G, McDougall K, Millar CI, Naylor BJ, Parks CG, Rew LJ, Seipel T (2009) Ain't no mountain high enough: plant invasions reaching new elevations. Front Ecol Environ 7:479-486. https://doi.org/10.1890/080072

Pauchard A, Milbau A, Albihn A, Alexander J, Burgess T, Daehler C, Englund G et al (2016) Non-native and native organisms moving into high elevation and high latitude ecosystems in an era of climate change: new challenges for ecology and conservation. Biol Invasions 18:345-353. https://doi.org/10.1007/s10530-015-1025-X

Pickering C, Mount A (2010) Do tourists disperse weed seed? A global review of unintentional human-mediated terrestrial seed dispersal on clothing, vehicles and horses. J Sustain Tour 18:239-256. https://doi.org/10.1080/ 09669580903406613

R Core Team (2018) R: a language and environment for statistical computing. R Foundation for Statistical Computing, Vienna

Rowe HI, Tluczek M, Broatch J, Gruber D, Jones S, Langenfeld D, McNamara P, Weinstein L (2018) Comparison of trailside degradation across a gradient of trail use in the Sonoran Desert. J Environ Manag 207:292-302. https:// doi.org/10.1016/j.jenvman.2017.11.028

Rumpf SB, Hülber K, Klonner G, Moser D, Schütz M, Wessely J, Willner W, Zimmermann NE, Dullinger S (2018) Climate-driven range dynamics of mountain plants decrease with elevation. Proc Natl Acad Sci 115:1848-1853. https:// doi.org/10.1073/pnas.1713936115

Seipel T, Kueffer C, Rew LJ, Daehler CC, Pauchard A, Naylor BJ, Alexander JM, Edwards PJ, Parks CG, Arevalo JR, Cavieres LA, Dietz H, Jakobs G, McDougall K, Otto R, Walsh N (2012) Processes at multiple scales affect richness and similarity of non-native plant species in mountains around the world: mountain invasions at multiple scales. Glob Ecol Biogeogr 21:236-246. https://doi.org/10.1111/j. 1466-8238.2011.00664.x

Seipel T, Alexander JM, Edwards PJ, Kueffer C (2016) Range limits and population dynamics of non-native plants spreading along elevation gradients. Perspect Plant Ecol Evol Syst 20:46-55. https://doi.org/10.1016/j.ppees.2016. 04.001

Sernageomin (2003) Carta Geológica de Chile (escala 1:1.000.000). Geológica Digital 4. Technical report, Santiago, Chile.

Steyn C, Greve M, Robertson MP, Kalwij JM, le Roux PC (2017) Alien plant species that invade high elevations are generalists: support for the directional ecological filtering hypothesis. J Veg Sci 28:337-346. https://doi.org/10.1111/ jvs. 12477

Veblen TT, Kitzberger T, Raffaele E, Mermoz M, González ME, Sibold JS, Holz A (2008) The historical range of variability of fires in the Andean-Patagonian Nothofagus forest region. Int J Wildland Fire 17:724-741. https://doi. org/10.1071/WF07152

Vilà M, Espinar JL, Hejda M, Hulme PE, Jarošík V, Maron JL, Pergl J, Schaffner U, Sun Y, Pyšek P (2011) Ecological impacts of invasive alien plants: a meta-analysis of their effects on species, communities and ecosystems: ecological impacts of invasive alien plants. Ecol Lett 14:702-708. https://doi.org/10.1111/j.1461-0248.2011.01628.x

Whinam J, Chilcott N, Bergstrom DM (2005) Subantarctic hitchhikers: expeditioners as vectors for the introduction of alien organisms. Biol Conserv 121:207-219

Yang M, Lu Z, Fan Z, Liu X, Hens L, De Wulf R, Ou X (2018) Distribution of non-native plant species along elevation gradients in a protected area in the eastern Himalayas, China. Alp Bot. https://doi.org/10.1007/s00035-018-02056

Publisher's Note Springer Nature remains neutral with regard to jurisdictional claims in published maps and institutional affiliations. 